Birlesik Dünya Arastırma

BD-CENTER

Innovasyon ve Yayıneılık Merkezi
Global Journal of Guidance and Counseling in Schools: Current Perspectives

Volume 10, Issue 3, (2020)
Global Journal of Guidance \& Counselling in Schools: Current Perspectives

www.gjgc.eu

\title{
*Message from Executive Editor
}

Dear reader,

It is a privilege for us to publish Volume 10, Number 3, of the Global Journal of Guidance and Counseling: Current Perspectives. The COVID-19 pandemic which surfaced in 2019 spread throughout the world, slowing down activities in various sectors. Most people have lost a sense of balance as a result of the pandemic. We therefore see the need to offer guidance and counselling to our readers, to help them maintain a balance amid this global pandemic.

The five (5) papers published in this current issue were carefully selected from a list of submitted papers. The current issue covers papers submitted from five different countries from three continents. The papers which were submitted by researchers from Northern Cyprus, Ghana, Iran, Nigeria and Zimbabwe cover a list of topics including; Examining the relationship between academic procrastination behaviours and problematic Internet usage of high school students during the COVID19 pandemic period; Relationship between personality factors and marital conflict resolution strategies among spouses in Abuja Municipal Area Council FCT Abuja; Peer pressure as a predictor of career decision-making among high school students in Midlands Province, Zimbabwe; Influence of demographic factors on guidance needs of teacher trainees in Ghana; Self-efficacy and identity statuses in students of Iran.

We would like to appreciate our highly skilled authors for their inputs and submissions for this issue. Our reviewers also worked hard to make sure the quality of accepted papers were of high quality and we acknowledge their efforts. Many thanks to our publishing team as well.

We desire that this issue inspires you and keeps you expectant for the next issue. Enjoy reading!!

Best regards

Assoc. Prof. Dr. Nur Demirbas Celik, Executive Editor

Alanya Alaadin Keykubat University, Turkey

* ADDRESS FOR CORRESPONDENCE: Assoc. Prof. Dr. Nur Demirbas Celik, Executive Editor, Alanya Alaadin Keykubat University, Turkey

E-mail address: gigc.editor@gmail.com 